Revista Brasil. Bot., V.33, n.1, p.185-200, jan.-mar. 2010

\title{
Anatomia comparada da folha e espata de espécies de Anthurium (Araceae) ocorrentes na Mata Atlântica
}

\author{
ANDRÉ MANTOVANI ${ }^{1,2}$, ARINAWA LIZ DEL PRADO FILARTIGA ${ }^{1} \mathrm{e}$ \\ MARCUS ALBERTO NADRUZ COELHO ${ }^{1}$
}

(recebido: 20 de dezembro de 2007; aceito: 04 de março de 2010)

\begin{abstract}
Comparative anatomy of leaf and spathe of Anthurium (Araceae) species from the Atlantic Rain Forest). Leaf and spathe anatomy of nine species of the genus Anthurium (sections Urospadix and Leptanthurium) were analyzed. Plant material was collected from different locations in Brazil and cultivated under identical conditions in the Instituto de Pesquisas Jardim Botânico do Rio de Janeiro. Our objective was to evaluate the diagnostic potential of leaf and spathe anatomy for taxonomic purposes. Leaves presented smooth and striated cuticle, epidermal cells randomly disposed, raised and non-raised stomata, epidermal glands, periclinal divisions of epidermal cells, raphides, druses, carotene and diosmin crystals, palisade parenchyma on the adaxial surface of the midrib and sclerenchymatic fibre sheath in the bundle. The spathes also presented smooth and striated cuticle, epidermal cells in parallel rows, raised and non-raised stomata, epidermal glands, raphides, druses and flavonoidic crystals, uniform mesophyll, and presence of sclerenchyma as fibre caps associated to the vascular bundles. The Anthurium species have differences between leaves and spathes based on anatomical characters, but clustering analysis did not separate the species from different sections. Results indicate that spathe can give a better resolution than leaves for segregation of species groups in Anthurium.
\end{abstract}

Key words - Leptanthurium, taxonomy, Urospadix

RESUMO - (Anatomia comparada da folha e espata de espécies de Anthurium (Araceae) ocorrentes na Mata Atlântica). São apresentados dados relativos à anatomia da lâmina foliar e espata de nove espécies do gênero Anthurium (seções Urospadix e Leptanthurium). Os indivíduos foram coletados em diversas partes do Brasil e aclimatados no Instituto de Pesquisas Jardim Botânico do Rio de Janeiro. O objetivo deste estudo foi comparar as características anatômicas da lâmina foliar e da espata, detectando caracteres que sejam potenciais para subsidiar e contribuir aos estudos taxonômicos do gênero Anthurium. Observa-se nas folhas a presença tanto de cutícula lisa quanto estriada, células epidérmicas dispostas ao acaso, estômatos no mesmo nível das demais células da epiderme ou elevados, glândulas epidérmicas e divisões periclinais em células epidérmicas, além de ráfides, drusas, cristais de caroteno e diosmina, parênquima paliçádico na face adaxial da nervura central e bainha de fibras esclerenquimáticas nos feixes. Quanto à espata observa-se cutícula lisa e estriada, células epidérmicas ordenadas de forma paralela, estômatos no mesmo nível das demais células da epiderme ou elevados, glândulas epidérmicas, ráfides, drusas e cristais de natureza flavonoídica; o mesofilo é uniforme, apresentando apenas calotas de fibras associadas aos feixes vasculares, quando não ausentes. As espécies de Anthurium avaliadas mostraram-se distintas quanto à anatomia de folha e espata, mas as análises de agrupamento não permitiram separar espécies de acordo com a respectiva seção. Os resultados indicam ser a espata a estrutura cuja anatomia apresenta maior potencial diagnóstico para segregação de grupos de espécies em Anthurium.

Palavras-chave - Leptanthurium, taxonomia, Urospadix

\section{Introdução}

A família Araceae possui atualmente 109 gêneros e cerca de 2.823 espécies (Govaerts et al.2002) concentradas predominantemente nos trópicos americanos, no Sudeste da Ásia e no Arquipélago da Malásia. No Brasil são encontradas aproximadamente 320 espécies distribuídas em 32 gêneros, dentre esses Bognera, Dracontioides, Gearum e Zomicarpa endêmicos, além de outros com

1. Instituto de Pesquisas Jardim Botânico do Rio de Janeiro, Rua Pacheco Leão 915, Jardim Botânico, 22460-030 Rio de Janeiro, RJ, Brasil.

2. Autor para correspondência: andre@jbrj.gov.br distribuição mais ampla como Philodendron e Anthurium (Schneider \& Coelho 2006, Coelho 2007).

O gênero Anthurium é o maior e provavelmente o mais complexo ao nível taxonômico na família Araceae (Coelho \& Mayo 2007), compreendendo cerca de 1.000 espécies. A maior parte dessas espécies são epífitas sensu-strictu, ocasionalmente hemi-epífitas, terrestres e rupícolas (Croat 1988, Mantovani 2000). Ocorrem nos trópicos americanos, distribuídas desde o México até a Argentina.

As publicações sobre a família Araceae incluem uma extensa lista sobre a anatomia foliar. Entretanto, são relativamente poucas as análises anatômicas realizadas no gênero Anthurium (Lindorf 1980, Rada 
\& Jaimez 1992, Mantovani 1999a, b), principalmente com enfoque taxonômico (Mantovani \& Pereira 2005, Mantovani et al. 2009). Podem ser citados para Anthurium os estudos de Gentner (1905) sobre o processo de gutação, de Lindorf (1980) sobre a ocorrência de glândulas foliares, de French (1997) sobre a presença de endoderme e de Rada \& Jaimez (1992), Mantovani (1999a, b) e Lorenzo et al. (2009) que avaliam a morfofisiologia de epífitas do gênero. Na recente revisão sobre a anatomia de Araceae, Keating (2002) mostra a existência de caracteres anatômicos foliares úteis para diagnósticos taxonômicos em diferentes gêneros. No entanto, são poucas as informações apresentadas para a espata. Mayo (1986) identificou caracteres anatômicos na espata de Philodendron. Já Mantovani \& Pereira (2005), trabalhando com nove espécies de Anthurium da seção Urospadix subseção Flavescentiviridia, comparam a anatomia de folha e espata revelando maior potencialidade da espata em gerar caracteres diagnósticos para taxonomia de Anthurium. Por fim, Mantovani et al. (2009) avaliaram a variação da morfologia da nervura central ao longo da lâmina foliar como caráter diagnóstico para a taxonomia de Anthurium.

Considerando o grande número de espécies, sua diversidade e complexidade, torna-se necessário dar ênfase a estudos anatômicos que visem subsidiar o conhecimento taxonômico do gênero Anthurium e suas subseções. Segundo Coelho $(2004,2009)$ o uso de estudos anatômicos, principalmente da espata, somado a um estudo mais detalhado da morfologia dos caracteres reprodutivos, seria de relevante contribuição na separação das espécies da subseção Flavescentiviridia, em vista da dificuldade em delimitar taxonomicamente alguns grupos considerados "complexos". O principal objetivo do presente trabalho é, portanto, comparar as características anatômicas da lâmina foliar e da espata, detectando caracteres que sejam potenciais para subsidiar e contribuir nos estudos taxonômicos do gênero Anthurium, com espécies das seções Urospadix e Leptanthurium.

\section{Material e métodos}

Foram estudas nove espécies de Anthurium pertencentes a três diferentes seções, todas ocorrentes em floresta ombrófila densa de Mata Atlântica: Anthurium acutum N. E. Brown (M. Nadruz 1554, RB 378504), A. intermedium Kunth (M. Nadruz 1375, RB 353666), A. loefgrenii Engler (M. Nadruz 1488, RB 365236), A. luschnatianum Kunth (M. Nadruz 1539, RB 376187), A. miquelianum Koch \& Augustin (M. Nadruz 1473, RB 364270), Anthurium sp. 1 (M. Nadruz 2325, RB 493673) (seção Urospadix subseção Flavescentiviridia), $A$. gracile (Rudge) Lindl. (M. Nadruz 2326, RB 493702) (seção Leptanthurium), A. minarum Sakuragui \& Mayo (M. Nadruz 1352, RB 353490) e Anthurium sp. 2 (M. Nadruz 1511, RB 368690) (seção Urospadix subseção Obscureviridia). Indivíduos foram coletados e cultivados sob condições abióticas semelhantes durante um período de três a sete anos em estufa no Instituto de Pesquisas Jardim Botânico do Rio de Janeiro e os respectivos materiais testemunho encontram-se depositados no herbário da instituição (RB). O clima da área de cultivo era do tipo Am (sensu Köeppen 1948), com a precipitação concentrada no verão e reduzida no inverno, com média anual de $1.075 \mathrm{~mm}$. As médias de temperatura durante o verão e o inverno eram equivalentes a $29^{\circ} \mathrm{C}$ e $22^{\circ} \mathrm{C}$, respectivamente (Mantovani \& Pereira 2005).

Folha e espata totalmente expandidas de cada uma das nove espécies foram coletadas, acondicionadas em sacos plásticos umedecidos e levadas ao laboratório onde foram então fixadas em FAA em etanol 70\% (Mantovani \& Vieira 2000). A partir do material fixado foram feitas seções transversais da região mediana da lâmina foliar e espata, obtidas com uso do vibrátomo ou a partir de material emblocado em resina, bem como seções paradérmicas obtidas à mão livre. Para cortes transversais com vibrátomo, pequenas seções $(0,3 \mathrm{~cm} \times 0,5 \mathrm{~cm})$ foram emblocadas em formas de plástico $(0,5 \mathrm{~mL}$ a $1 \mathrm{~mL})$ com solução de agarose em água destilada ( $0,6 \mathrm{~g}$ do soluto em $10 \mathrm{~mL}$ de solvente). A solução líquida foi previamente aquecida até ficar translúcida e posteriormente colocada nas formas de plástico com o material (Ruzin 1992). Depois da solução esfriar e endurecer ( $c$. de $1 \mathrm{~min}$ ), os blocos foram desenformados e trabalhados no vibrátomo. Seções transversais com espessura aproximada de $5 \mu \mathrm{m}$ foram clarificadas em hipoclorito de sódio, coradas com uma solução de safranina aquosa $0,5 \%$ - azul de astra 0,5\%, 4:6 (v/v) e montadas em lâminas semipermanentes com glicerina 50\%. Para emblocamento em resina, seções de $1,2 \mathrm{~cm} \times 0,3 \mathrm{~cm}$ foram inicialmente fixadas em glutaraldeído, desidratadas em série alcoólica crescente e incluídas em resina de hidroxietilmetacrilato. Seções transversais com espessura aproximada de $3 \mu \mathrm{m}$ foram obtidas utilizando micrótomo rotativo Spencer e coradas com azul de toluidina O (O’Brien \& McCully 1981). Por fim, cortes paradérmicos foram obtidos à mão livre, clarificados com hipoclorito de sódio, corados com safranina aquosa $0,5 \%$ (Johansen 1940) e montados em lâminas semipermanentes.

Testes histoquímicos foram realizados em cortes paradérmicos de $A$. gracile e $A$. minarum, visto que análises prévias sob microscopia de polarização demonstraram presença de estruturas cristalinas distintas dos cristais de oxalato de cálcio usualmente encontradas em Anthurium (Gemia \& Hillson 1985, Keating 2000, Mantovani \& Pereira 2005). A possível natureza flavonoídica destes cristais foi avaliada através dos seguintes testes: solubilidade em hidróxido de sódio a $5 \%$ e insolubilidade em hidróxido de amônia para a identificação de cristais de diosmina, insolubilidade em solução de álcool etílico e ácido acético (1:1) para identificar cristais de hesperidina. Já a detecção 
de cristais de caroteno foi avaliada pela ocorrência ou não de alteração cromática das estruturas cristalinas após aplicação de solução de ácido sulfúrico e água destilada (1:1) (Metcalfe \& Chalk 1979). Fotomicrografias digitais foram obtidas utilizando câmera digital Coolsnap acoplada ao microscópio ótico Olympus BX-50.

A classificação das células e dos tecidos seguiu a nomenclatura proposta por Keating $(2000,2002)$.

Folha e espata foram comparadas quanto ao potencial diagnóstico para taxonomia dos respectivos caracteres anatômicos, através de análises de agrupamento (Mantovani $\&$ Pereira 2005). Foram estabelecidos 25 caracteres para folha e 21 para espata. Os dados foram descritos como presença (1) e ausência (0), sendo feita uma análise de agrupamento utilizando a distância Euclidiana e método do UPGMA como algoritmo. Foram consideradas significativas as análises de agrupamento com índice cofenético superior a 0,7 (Valentin 2000).

\section{Resultados}

Anatomia da folha - Seções paradérmicas das faces adaxial e abaxial das folhas são mostradas nas figuras 1 a 8 . As células epidérmicas são poligonais e apresentam tamanhos semelhantes, com paredes anticlinais retas ou levemente onduladas. Exceção é representada em A. gracile com células maiores (figura 1), quando comparada às outras espécies em mesmo aumento como Anthurium sp. 2 (figura 2). Todas as espécies estudadas apresentam estômatos distribuídos aleatoriamente na face abaxial da folha, enquanto na face adaxial os estômatos estão concentrados apenas na nervura central. Os tipos estomáticos encontrados foram braquiparacítico e suas variações (anfibraquiparacítico, braquiparatetracítico, hexacítico e octocítico) e o unipolar (figuras 3-6). A ocorrência dos tipos estomáticos varia de quatro a seis por espécie, sendo que os tipos braquiparacítico e unipolar (figura 5) ocorrem na maioria das espécies (tabela 1). As células subsidiárias dos estômatos braquiparacíticos são largas em todas as espécies. Glândulas punctiformes de tamanhos variados, constituídas por células dispostas de forma radiada, ocorrem aleatoriamente apenas na epiderme da face abaxial da folha de $A$. minarum (figura 7).

A epiderme foliar de todas as espécies é uniestratificada, constituída por células tabulares quando observadas transversalmente. Os estômatos em seção transversal podem estar no mesmo nível das demais células epidérmicas ou acima delas (figuras 9-10). Apenas $A$. miquelianum apresenta divisões periclinais da epiderme em ambas as faces; já a espécie $A$. gracile apresenta hipoderme na face abaxial.
O mesofilo de todas as espécies é dorsiventral, com parênquima paliçádico dotado de células pouco alongadas disposto entre uma a três camadas celulares (figuras 11-12) e o parênquima esponjoso entre sete a 19 camadas. A face adaxial da nervura principal de todas as espécies é constituída por um tecido colenquimatoso imediatamente adjacente à epiderme (figura 13). Entretanto em Anthurium sp. 1 o parênquima paliçádico ocorre também junto à epiderme da face adaxial da nervura central, conectando as duas regiões intercostais da folha (figura 14). Tal fato, nesta espécie, não limitou a ocorrência de parênquima colenquimatoso na nervura central, situado abaixo do parênquima paliçádico citado.

O esclerênquima é representado apenas por bainha de fibras esclerenquimáticas nos feixes vasculares (figura 15). Nas seções transversais os feixes são colaterais e constituídos por vários elementos de protoxilema e metaxilema associados ao floema.

Idioblastos contendo drusas se distribuem na face adaxial em $A$. loefgrenii, A. minarum e Anthurium sp. 1 e na face abaxial somente em $A$. minarum. Em seção transversal drusas são muito freqüentes no parênquima de todas as espécies (tabela 2). Ráfides também ocorrem no parênquima do mesofilo e da nervura central (figura 16), porém em menor quantidade, sendo ausentes nas espécies $A$. acutum, $A$. luschnatianum, A. minarum e A. miquelianum. Estruturas de coloração amarelada, compostas por feixes de cristais em forma de agulha dispostos de maneira concêntrica, foram encontrados na epiderme das duas faces da folha de A. gracile (figuras 8-9) e A. minarum, eventualmente no parênquima esponjoso de A. gracile. Tais estruturas mostraram-se solúveis quando tratadas com hidróxido de sódio e insolúveis em hidróxido de amônio, resultado que indica cristais de natureza flavonoídica, mais especificamente de diosmina. Simultaneamente não houve solubilidade sob solução de álcool e ácido acético, afastando a possibilidade da presença de hesperedina. Cristais prismáticos do tipo acicular, de coloração alaranjada brilhante foram eventualmente encontrados no mesofilo de $A$. gracile, A. intermedium, Anthurium sp. 1 e A. miquelianum. A verificação da composição química destes cristais, efetuada utilizando ácido sulfúrico, revelou alteração cromática do laranja para azul, indicando presença de caroteno.

Anatomia da espata - Seções paradérmicas das faces adaxial e abaxial das espatas são mostradas na figuras 17 a 24. As células são retangulares variando de curtas a mediano alongadas, sempre orientadas em fileiras longitudinais. A maioria das espécies apresenta células 

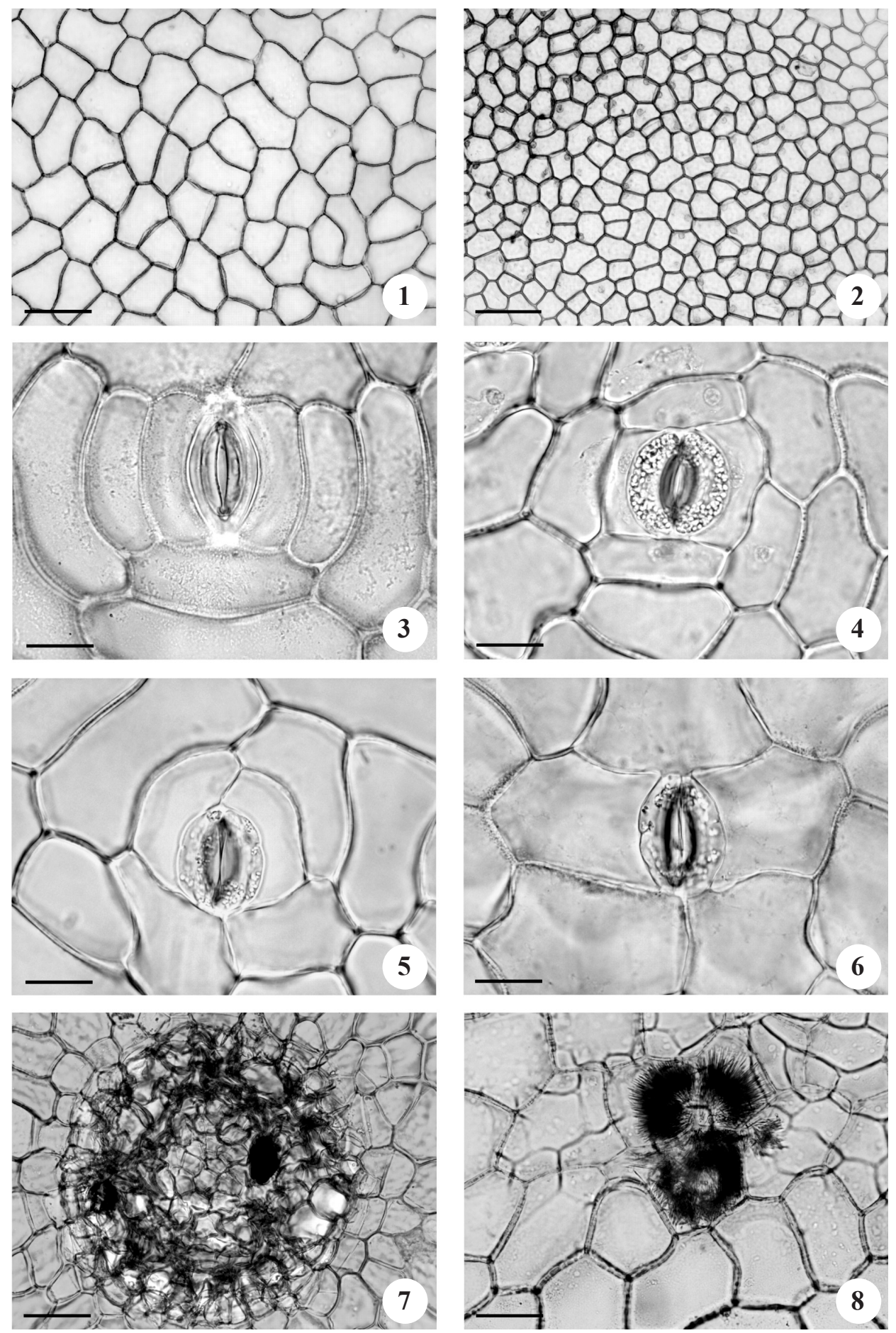

Figuras 1-8. Epiderme foliar. Faces adaxial $(1,2,8)$ e abaxial (3-7), visão paradérmica. 1. Anthurium gracile, células epidérmicas grandes. 2. Anthurium sp. 2, células epidérmicas pequenas. 3. A. luschnatianum, estômato anfibraquiparacítico. 4. A. acutum, estômato braquiparatetracítico. 5. A. intermedium, estômato unipolar. 6. A. intermedium, estômato braquiparacítico longo. 7. A. minarum, glândula epidérmica. 8. A. gracile, feixe concêntrico de estruturas cristalinas. Barra $=100 \mu \mathrm{m}(1,2), 25 \mu \mathrm{m}(3-6)$, $50 \mu \mathrm{m}(7,8)$.

Figures 1-8. Leaf epidermis. Adaxial (1, 2, 8) and abaxial (3-7) surfaces, paradermal view. 1. Anthurium gracile, large epidermal cells. 2. Anthurium sp. 2, small epidermal cells. 3. A. luschnatianum, amphibrachyparacytic stoma. 4. A. acutum, brachyparatetracytic stoma. 5. A. intermedium, unipolar stoma. 6. A. intermedium, brachyparacytic stoma with long subsidiary cells. 7. A. minarum, epidermal gland. 8. A. gracile, concentric crystals. $B a r=100 \mu \mathrm{m}(1,2), 25 \mu \mathrm{m}(3-6), 50 \mu \mathrm{m}(7,8)$. 
Tabela 1. Caracteres anatômicos da epiderme da folha de espécies de Anthurium. (ABP $=$ anfibraquiparacítico; $\mathrm{BP}=$ braquiparacítico; $\mathrm{BPT}=$ braquiparatetracítico; $\mathrm{BPH}=$ braquiparahexacítico; $\mathrm{BPO}=$ braquiparaoctocítico; $\mathrm{UNI}=$ unipolar).

Table 1. Leaf epidermis anatomical characters from species of Anthurium. $(\mathrm{ABP}=$ anfibrachyparacytic; $\mathrm{BP}=$ brachyparacytic; $\mathrm{BPT}=$ brachyparatetracytic; $\mathrm{BPH}=$ brachyparahexacytic; $\mathrm{BPO}=$ brachyparaoctocytic; $\mathrm{UNI}=$ unipolar $)$.

\begin{tabular}{|c|c|c|c|c|}
\hline \multirow[b]{2}{*}{ Espécies } & \multicolumn{4}{|c|}{ Caracteres } \\
\hline & $\begin{array}{l}\text { Células epidérmicas } \\
\text { da face adaxial }\end{array}$ & $\begin{array}{c}\text { Células epidérmicas } \\
\text { da face abaxial }\end{array}$ & $\begin{array}{l}\text { Tipos estomáticos } \\
\text { (face abaxial) }\end{array}$ & $\begin{array}{l}\text { Tamanho das células } \\
\text { subsidiárias dos estômatos } \\
\text { braquiparacíticos } \\
\text { (face abaxial) }\end{array}$ \\
\hline A. acutum & $\begin{array}{l}\text { Pequenas; paredes } \\
\text { anticlinais retas a } \\
\text { levemente onduladas }\end{array}$ & $\begin{array}{l}\text { Pequenas; paredes } \\
\text { anticlinais retas a } \\
\text { levemente onduladas }\end{array}$ & BP; ABP; BPT; UNI & Larga \\
\hline A. gracile & $\begin{array}{l}\text { Grandes; paredes } \\
\text { anticlinais retas a } \\
\text { levemente onduladas }\end{array}$ & $\begin{array}{l}\text { Grandes; paredes } \\
\text { anticlinais retas a } \\
\text { levemente onduladas }\end{array}$ & BP; ABP; BPH; UNI & Larga \\
\hline A. intermedium & $\begin{array}{l}\text { Pequenas; paredes } \\
\text { anticlinais retas a } \\
\text { levemente onduladas }\end{array}$ & $\begin{array}{l}\text { Pequenas; paredes } \\
\text { anticlinais retas a } \\
\text { levemente onduladas }\end{array}$ & $\begin{array}{l}\text { BP; BP (longo); ABP; } \\
\text { BPT; BPH; UNI }\end{array}$ & Larga \\
\hline A. loefgrenii & $\begin{array}{l}\text { Pequenas; paredes } \\
\text { anticlinais retas a } \\
\text { levemente onduladas }\end{array}$ & $\begin{array}{l}\text { Pequenas; paredes } \\
\text { anticlinais onduladas }\end{array}$ & $\begin{array}{l}\text { BP; BP (longo); ABP; } \\
\text { BPT; UNI }\end{array}$ & Larga \\
\hline A. luschnatianum & $\begin{array}{l}\text { Pequenas; paredes } \\
\text { anticlinais retas a } \\
\text { levemente onduladas }\end{array}$ & $\begin{array}{l}\text { Pequenas; paredes } \\
\text { anticlinais onduladas }\end{array}$ & $\begin{array}{l}\text { BP; BP (longo); ABP; } \\
\text { BPT; UNI }\end{array}$ & Larga \\
\hline Anthurium sp. 1 & $\begin{array}{l}\text { Pequenas; paredes } \\
\text { anticlinais levemente } \\
\text { onduladas }\end{array}$ & $\begin{array}{l}\text { Pequenas; paredes } \\
\text { anticlinais onduladas }\end{array}$ & $\begin{array}{l}\text { BP; ABP; BPT, BPH, } \\
\text { BPO, UNI }\end{array}$ & Larga \\
\hline A. minarum & $\begin{array}{l}\text { Pequenas; paredes } \\
\text { anticlinais retas }\end{array}$ & $\begin{array}{l}\text { Pequenas; paredes } \\
\text { anticlinais retas a } \\
\text { levemente onduladas }\end{array}$ & $\begin{array}{l}\text { BP; BP (longo); BPT, } \\
\text { BPH, UNI }\end{array}$ & Larga \\
\hline A. miquelianum & $\begin{array}{l}\text { Pequenas; paredes } \\
\text { anticlinais levemente } \\
\text { onduladas }\end{array}$ & $\begin{array}{l}\text { Pequenas; paredes } \\
\text { anticlinais onduladas }\end{array}$ & $\begin{array}{l}\text { BP; BP (longo); ABP; } \\
\text { BPT; BPH, UNI }\end{array}$ & Larga \\
\hline Anthurium sp. 2 & $\begin{array}{l}\text { Pequenas; paredes } \\
\text { anticlinais retas }\end{array}$ & $\begin{array}{l}\text { Pequenas; paredes } \\
\text { anticlinais retas a } \\
\text { levemente onduladas }\end{array}$ & BP; ABP; BPH, UNI & Larga \\
\hline
\end{tabular}

epidérmicas curtas na face adaxial (figuras 18-20), sendo este tipo celular ausente na face abaxial de todas as espécies. As células de tamanho mediano foram encontradas apenas na face adaxial em $A$. intermedium (figura 17). No entanto, na face abaxial elas estavam presentes em A. acutum, A. gracile, A. minarum (figura 22), A. miquelianum e Anthurium sp. 2 (figura 23). As paredes anticlinais das células epidérmicas da face abaxial de todas as espécies variam de retas a levemente onduladas (tabela 3). Essas células geralmente apresentam bordas retas na face adaxial em $A$. acutum, A. gracile, A. loefgrenii, Anthurium sp. 1, A. minarum e A. miquelianum, e bordas oblíquas na face abaxial, exceto em $A$. miquelianum.

Todas as espécies apresentam estômatos nas duas faces da espata. Os tipos estomáticos encontrados foram 

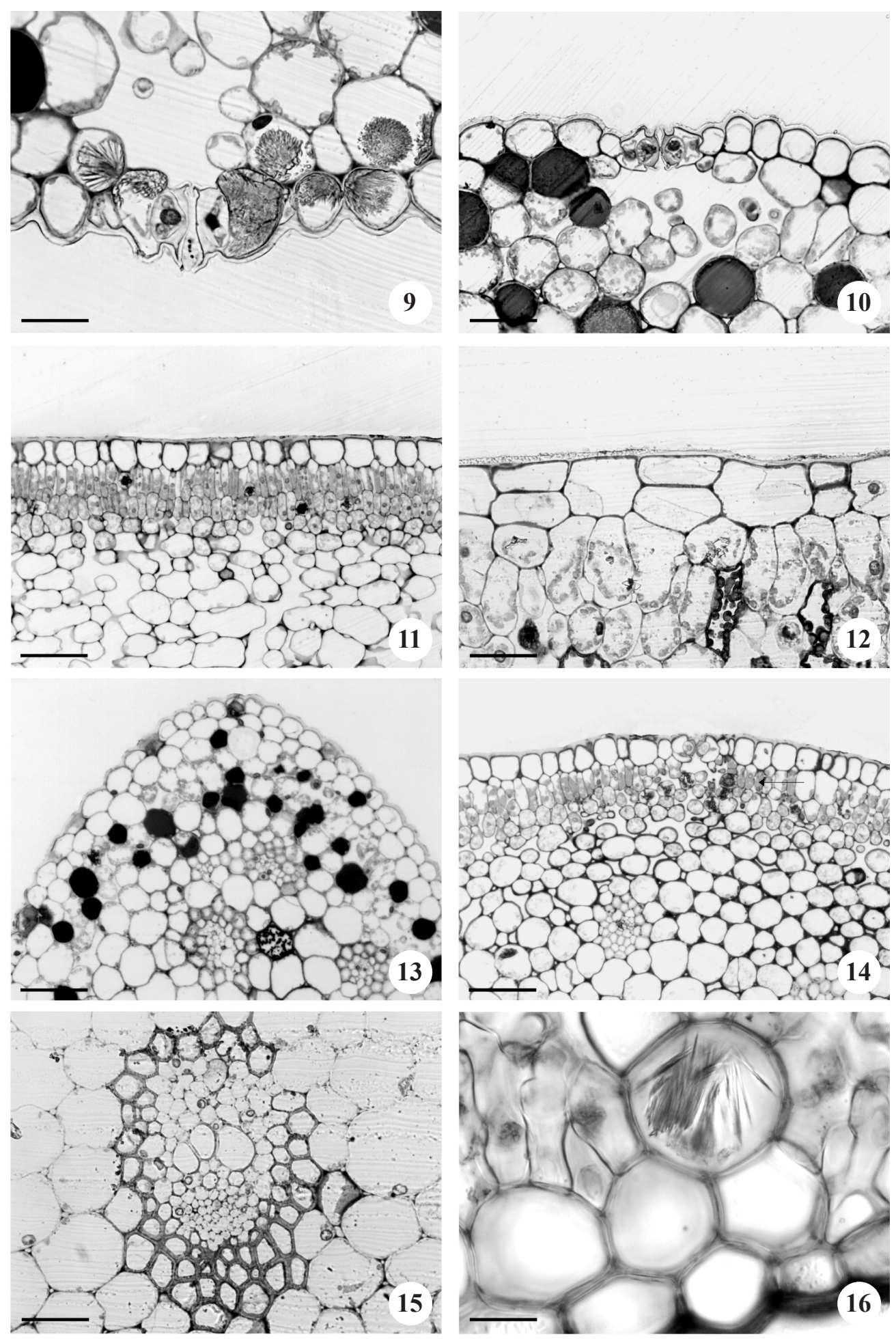

Figuras 9-16. Lâmina foliar. Seções transversais. 9. Anthurium gracile, estômato elevado, cutícula lisa e feixes concêntricos de cristais na epiderme da face abaxial (nervura central). 10. A. gracile, estômato no mesmo nível das células epidérmicas da face abaxial (nervura central). 11. Anthurium sp. 1, parênquima paliçádico com duas a três camadas (região intercostal). 12. A. miquelianum, células do parênquima paliçádico pouco alongadas e divisões periclinais da epiderme na face adaxial (região intercostal). 13. A. gracile, face adaxial da nervura central. Note a ausência do parênquima paliçádico. 14. Anthurium sp. 1, face adaxial da nervura central. Note a presença de estômato, parênquima paliçádico e colênquima logo abaixo. 15. Anthurium sp. 2, feixe vascular com bainha de fibras esclerenquimáticas. 16. A. gracile, ráfides no parênquima (nervura principal). Barra $=25 \mu \mathrm{m}(9,16), 50 \mu \mathrm{m}(10,12,15), 100 \mu \mathrm{m}(11,13,14)$. 
Tabela 2. Anatomia foliar de espécies de Anthurium, seção transversal. (Presença (1) ou ausência (0) dos caracteres selecionados. Caracteres: 1 = drusas (epiderme da face abaxial, região intercostal); 2 = drusas (epiderme da face adaxial, nervura central); $3=$ drusas (epiderme da face abaxial, região intercostal); $4=$ drusas (epiderme da face abaxial, nervura central); $5=$ drusas (parênquima paliçádico); 6 = drusas (parênquima esponjoso); $7=$ ráfides (clorênquima, nervura central); 8 = ráfides (mesofilo, região intercostal); 9 = parênquima paliçádico (face adaxial, nervura central); 10 = estômatos (face adaxial, região intercostal); 11 = estômatos (face adaxial, nervura central); 12 = estômatos (face abaxial, região intercostal); 13 = estômatos (epiderme da face abaxial, nervura central); 14 = divisões periclinais na epiderme; 15 = colênquima (face adaxial, nervura central); 16 = cutícula lisa (epiderme da face adaxial, região intercostal); 17 = cutícula lisa (epiderme da face adaxial, nervura central); 18 = cutícula lisa (epiderme da face abaxial, região intercostal); 19 = cutícula lisa (epiderme da face abaxial, nervura central); 20 = cristais prismáticos (mesofilo); 21 = estômatos elevados (epiderme da face abaxial, região intercostal); 22 = estômatos elevados (epiderme da face abaxial, nervura central); 23 = estômatos elevados (epiderme da face adaxial, nervura central); 24 = cristais de natureza flavonoídica na epiderme; 25 = glândulas na epiderme).

Table 2. Leaf anatomy of Anthurium species, transversal view. (Presence (1) or absence (0) of selected characters. Characters: $1=$ druses (adaxial surface epidermis, intercostal region); 2 = druses (adaxial surface epidermis, midrib); $3=$ druses (abaxial surface epidermis, intercostal region); $4=$ druses (abaxial surface epidermis, midrib); $5=$ druses (palisade parenchyma); $6=$ druses (spongy parenchyma); 7 = raphides (chlorenchyma, midrib); $8=$ raphides (mesophyll, intercostal region); $9=$ palisade parenchyma (adaxial surface, midrib); $10=$ stomata (adaxial surface epidermis, intercostal region); $11=$ stomata (adaxial surface epidermis, midrib); 12 = stomata (abaxial surface epidermis, intercostal region); 13 = stomata (abaxial surface epidermis, midrib); $14=$ periclinal divisions on epidermis; 15 = collenchyma (adaxial surface, midrib); $16=$ smooth cuticle (adaxial surface epidermis, intercostal region); 17 = smooth cuticle (adaxial surface epidermis, midrib); $18=$ smooth cuticle (abaxial surface epidermis, intercostal region); $19=$ smooth cuticle (abaxial surface epidermis, midrib); $20=$ prismatic crystals (mesophyll); $21=$ raised stomata (abaxial surface epidermis, intercostal region); 22 = raised stomata (abaxial surface epidermis, midrib); 23 = raised stomata (adaxial surface epidermis, midrib); 24 = flavonoid crystals on the epidermis; 25 = glands on the epidermis).

\begin{tabular}{lcccccccccccccccccccccccccc}
\hline Espécies & 1 & 2 & 3 & 4 & 5 & 6 & 7 & 8 & 9 & 10 & 11 & 12 & 13 & 14 & 15 & 16 & 17 & 18 & 19 & 20 & 21 & 22 & 23 & 24 & 25 \\
\hline A. acutum & 0 & 0 & 0 & 0 & 1 & 1 & 0 & 0 & 0 & 0 & 1 & 1 & 0 & 0 & 1 & 1 & 0 & 1 & 0 & 0 & 0 & 0 & 0 & 0 & 0 \\
A. gracile & 0 & 0 & 0 & 0 & 1 & 1 & 1 & 0 & 0 & 0 & 1 & 1 & 1 & 0 & 1 & 1 & 0 & 1 & 1 & 1 & 0 & 0 & 0 & 1 & 0 \\
A. intermedium & 1 & 1 & 0 & 0 & 1 & 1 & 1 & 0 & 0 & 0 & 1 & 1 & 1 & 0 & 1 & 1 & 1 & 1 & 1 & 1 & 0 & 1 & 0 & 0 & 0 \\
A. loefgrenii & 1 & 0 & 1 & 0 & 1 & 1 & 1 & 1 & 0 & 0 & 1 & 1 & 1 & 0 & 1 & 1 & 1 & 1 & 1 & 0 & 0 & 1 & 0 & 0 & 0 \\
A. luschnatianum & 0 & 0 & 0 & 1 & 1 & 1 & 0 & 0 & 0 & 0 & 1 & 1 & 1 & 0 & 1 & 1 & 1 & 1 & 1 & 0 & 0 & 0 & 0 & 0 & 0 \\
Anthurium sp. 1 & 1 & 0 & 1 & 1 & 1 & 1 & 1 & 0 & 1 & 0 & 1 & 1 & 1 & 0 & 1 & 1 & 0 & 0 & 0 & 1 & 0 & 0 & 0 & 0 & 0 \\
A. minarum & 1 & 1 & 1 & 1 & 1 & 1 & 0 & 0 & 0 & 0 & 1 & 1 & 1 & 0 & 1 & 0 & 1 & 0 & 1 & 0 & 0 & 0 & 0 & 0 & 1 \\
A. miquelianum & 1 & 1 & 1 & 1 & 1 & 1 & 0 & 0 & 0 & 0 & 1 & 1 & 1 & 1 & 1 & 1 & 1 & 1 & 1 & 1 & 0 & 0 & 1 & 0 & 0 \\
Anthurium sp. 2 & 0 & 0 & 0 & 0 & 1 & 1 & 0 & 1 & 0 & 0 & 1 & 1 & 0 & 0 & 1 & 1 & 1 & 1 & 1 & 0 & 0 & 0 & 0 & 0 & 0 \\
\hline
\end{tabular}

braquiparacítico, suas variações (anfibraquiparacítico, braquiparatetracítico e hexacítico), anisocítico e anomocítico (figuras 21-24). A ocorrência dos tipos estomáticos varia de um a cinco nas duas faces da espata (tabela 3). O tipo braquiparacítico ocorre na maioria das espécies, exceto em $A$. miquelianum.
Epiderme uniestratificada com células tabulares foram encontradas em todas as espécies (figuras 25-28). Somente $A$. minarum apresenta as células epidérmicas da face abaxial mais altas que largas (figura 28). A cutícula da epiderme em ambas as faces varia de lisa (figuras 26), levemente estriada a muito estriada

Figures 9-16. Leaf blade. Transversal sections. 9. Anthurium gracile, raised stoma, smooth cuticle and concentric crystals on the abaxial surface epidermis (midrib). 10. A. gracile, stoma at the same level of the abaxial surface epidermal cells (midrib). 11. Anthurium sp. 1, 2-3 layered palisade parenchyma (intercostal region). 12. A. miquelianum, palisade parenchyma composed by short cells and periclinal divisions on epidermal cells of adaxial surface (intercostal region). 13. A. gracile, adaxial surface of the midrib. Note absence of palisade parenchyma. 14. Anthurium sp. 1, adaxial surface of the midrib. Note presence of stoma, palisade parenchyma (arrow) and the adjacent collenchyma. 15. Anthurium sp. 2, vascular bundle with sclerenchymatic fibre sheath. 16. A. gracile, raphides in a parenchymatic cell (midrib). $\operatorname{Bar}=25 \mu \mathrm{m}(9,16), 50 \mu \mathrm{m}(10,12,15), 100 \mu \mathrm{m}(11,13,14)$. 

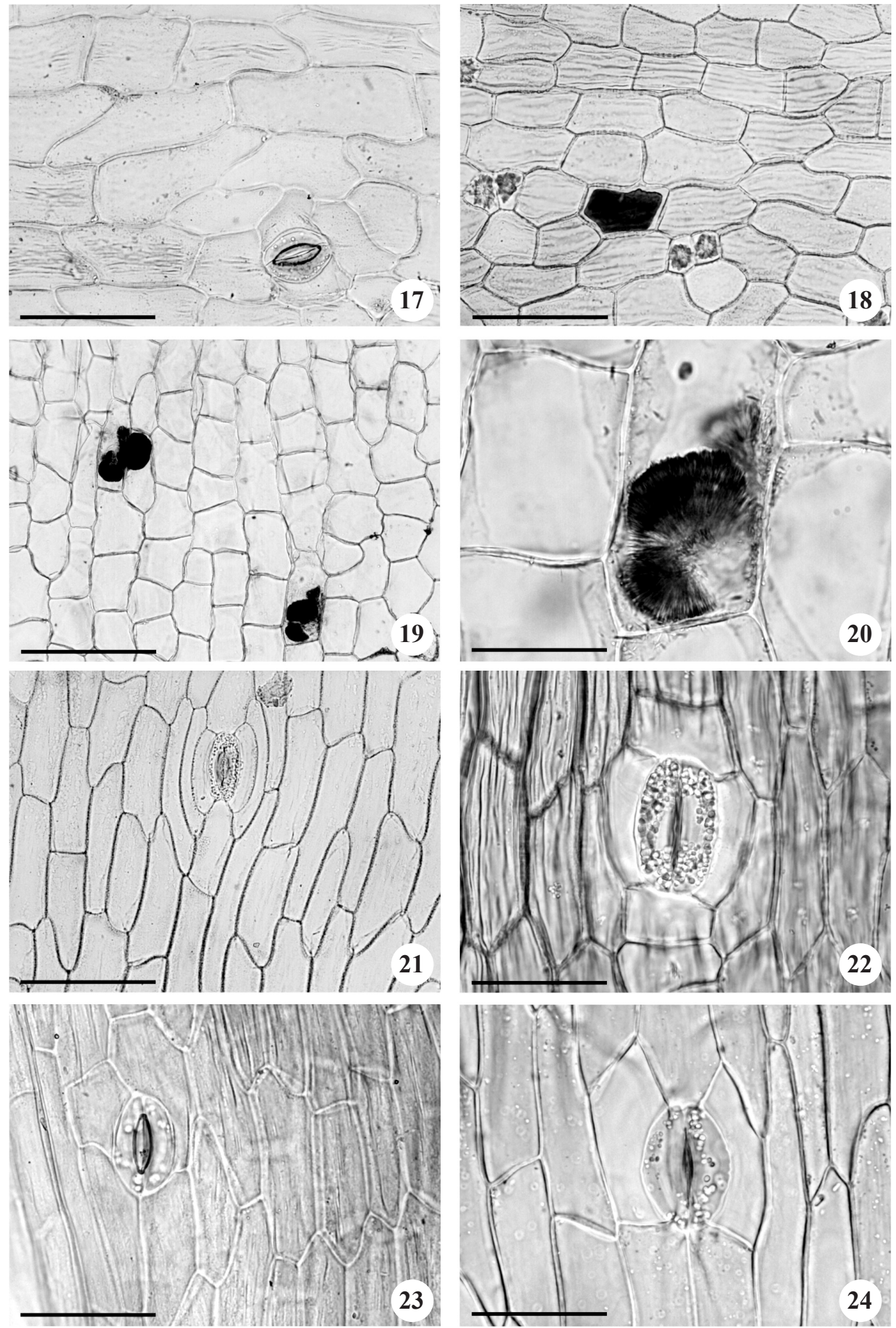

Figuras 17-24. Epiderme da espata. Visão paradérmica das faces adaxial (17-20) e abaxial (21-24). 17. Anthurium intermedium, fileiras paralelas de células epidérmicas de tamanho mediano. Note a cutícula pouco estriada. 18. A. minarum, fileiras paralelas de células epidérmicas curtas. Note a cutícula muito estriada. 19. A. gracile, feixe concêntrico de estruturas cristalinas. Note as células epidérmicas curtas e a cutícula lisa. 20. A. gracile, detalhe do feixe concêntrico de estruturas cristalinas. 21. A. luschnatianum, estômato anfibraquiparacítico. Note as células epidérmicas longas. 22. A. minarum, estômato braquiparatetracítico. Note a cutícula muito estriada. 23. Anthurium sp. 2, estômato anomocítico. 24. A. intermedium, estômato braquiparacítico. Barra $=$ $25 \mu \mathrm{m}(20,22-24), 50 \mu \mathrm{m}(17,18,21), 100 \mu \mathrm{m}(19)$. 
Tabela 3. Anatomia da espata de espécies de Anthurium, seção paradérmica da epiderme. (ABP = anfibraquiparacítico; $\mathrm{BP}=$ braquiparacítico; $\mathrm{BPT}=$ braquiparatetracítico; $\mathrm{BPH}=$ braquiparahexacítico $; \mathrm{BPO}=$ braquiparaoctocítico; $\mathrm{UNI}=$ unipolar; $\mathrm{ANOMO}=$ anomocítico; $\mathrm{ANISO}=$ anisocítico) .

Table 3. Spathe anatomical characters from species of Anthurium, paradermal view of the epidermis. $(\mathrm{ABP}=$ anfibrachyparacytic; $\mathrm{BP}=$ brachyparacytic; $\mathrm{BPT}=$ brachyparatetracytic; $\mathrm{BPH}=$ brachyparahexacytic; $\mathrm{BPO}=$ brachyparaoctocytic; $\mathrm{UNI}=$ unipolar; ANOMO = anomocytic; ANISO = anisocytic).

\begin{tabular}{|c|c|c|c|c|c|c|c|}
\hline \multirow[b]{2}{*}{ Espécies } & \multicolumn{7}{|c|}{ Caracteres } \\
\hline & $\begin{array}{c}\text { Células } \\
\text { epidérmicas da } \\
\text { face adaxial }\end{array}$ & $\begin{array}{c}\text { Células } \\
\text { epidérmicas da } \\
\text { face abaxial }\end{array}$ & $\begin{array}{l}\text { Parede } \\
\text { oblíqua } \\
\text { (face } \\
\text { adaxial) }\end{array}$ & $\begin{array}{l}\text { Parede } \\
\text { oblíqua } \\
\text { (face } \\
\text { abaxial) }\end{array}$ & $\begin{array}{l}\text { Tipos } \\
\text { estomáticos } \\
\text { (face } \\
\text { adaxial) }\end{array}$ & $\begin{array}{l}\text { Tipos } \\
\text { estomáticos } \\
\text { (face } \\
\text { abaxial) }\end{array}$ & $\begin{array}{c}\text { Tamanho } \\
\text { das células } \\
\text { subsidiárias } \\
\text { dos estômatos } \\
\text { braquiparacíticos } \\
\text { (face abaxial) }\end{array}$ \\
\hline A. acutum & $\begin{array}{l}\text { Curtas; paredes } \\
\text { anticlinais retas }\end{array}$ & $\begin{array}{l}\text { Médias; paredes } \\
\text { anticlinais retas }\end{array}$ & Ausente & Presente & $\begin{array}{l}\mathrm{BP} ; \mathrm{ABP} ; \\
\mathrm{BPH}\end{array}$ & $\mathrm{BP} ; \mathrm{ABP}$ & Larga \\
\hline A. gracile & $\begin{array}{l}\text { Curtas; paredes } \\
\text { anticlinais retas }\end{array}$ & $\begin{array}{l}\text { Médias; paredes } \\
\text { anticlinais retas }\end{array}$ & Presente & Presente & $\begin{array}{l}\text { BP; } \\
\text { ANOMO }\end{array}$ & BP; BPT & $\begin{array}{l}\text { Estreita e } \\
\text { Larga }\end{array}$ \\
\hline A. intermedium & $\begin{array}{l}\text { Médias; paredes } \\
\text { anticlinais retas }\end{array}$ & $\begin{array}{l}\text { Longas; paredes } \\
\text { anticlinais retas }\end{array}$ & Presente & Presente & $\begin{array}{l}\text { BP; ABP; } \\
\text { BPT; BPH }\end{array}$ & $\begin{array}{l}\text { BP; ANISO; } \\
\text { ANOMO }\end{array}$ & Larga \\
\hline A. loefgrenii & $\begin{array}{l}\text { Curtas; paredes } \\
\text { anticlinais retas }\end{array}$ & $\begin{array}{l}\text { Longas; paredes } \\
\text { anticlinais retas }\end{array}$ & Ausente & Presente & BP; ABP & $\begin{array}{l}\text { BP; ABP; } \\
\text { ANISO; } \\
\text { ANOMO }\end{array}$ & Estreita \\
\hline A. luschnatianum & $\begin{array}{l}\text { Curtas; paredes } \\
\text { anticlinais retas }\end{array}$ & $\begin{array}{l}\text { Longas; paredes } \\
\text { anticlinais retas a } \\
\text { onduladas }\end{array}$ & Presente & Presente & $\begin{array}{l}\text { BP; ABP; } \\
\text { BPT; BPH; } \\
\text { ANISO }\end{array}$ & $\begin{array}{l}\text { BP; ABP; } \\
\text { BPT, BPH; } \\
\text { ANISO }\end{array}$ & Estreita \\
\hline Anthurium sp. 1 & $\begin{array}{l}\text { Curtas; paredes } \\
\text { anticlinais } \\
\text { onduladas }\end{array}$ & $\begin{array}{l}\text { Longas; paredes } \\
\text { anticlinais retas a } \\
\text { onduladas }\end{array}$ & Ausente & Presente & BP & BP; ANISO & Estreita \\
\hline A. minarum & $\begin{array}{l}\text { Curtas; paredes } \\
\text { anticlinais retas }\end{array}$ & $\begin{array}{l}\text { Médias; paredes } \\
\text { anticlinais retas }\end{array}$ & Ausente & Presente & $\begin{array}{l}\text { BP; } \\
\text { ANOMO }\end{array}$ & $\begin{array}{l}\text { BP; BPT; } \\
\text { BPH; } \\
\text { ANOMO }\end{array}$ & Estreita \\
\hline A. miquelianum & $\begin{array}{l}\text { Longas; paredes } \\
\text { anticlinais retas }\end{array}$ & $\begin{array}{l}\text { Médias; paredes } \\
\text { anticlinais retas }\end{array}$ & Presente & Ausente & $\begin{array}{l}\text { ABP; BPH, } \\
\text { ANOMO; } \\
\text { ANISO }\end{array}$ & $\begin{array}{l}\text { ABP; BPT, } \\
\text { ANOMO }\end{array}$ & Estreita \\
\hline Anthurium sp. 2 & $\begin{array}{l}\text { Curtas; paredes } \\
\text { anticlinais retas }\end{array}$ & $\begin{array}{l}\text { Médias; paredes } \\
\text { anticlinais retas }\end{array}$ & Presente & Presente & $\begin{array}{l}\text { BP; } \\
\text { ANOMO }\end{array}$ & $\begin{array}{l}\text { BP; BPT, } \\
\text { ANOMO }\end{array}$ & $\begin{array}{l}\text { Estreita e } \\
\text { Larga }\end{array}$ \\
\hline
\end{tabular}

Figures 17-24. Spathe epidermis. Adaxial (17-20) and abaxial (21-24) surfaces in paradermal view. 17. Anthurium intermedium, parallel rows of medium sized epidermal cells. Note light cuticular striations. 18. A. minarum, parallel rows of short epidermal cells. Note conspicuous cuticular striations. 19. A. gracile, concentric crystals. Note short epidermal cells and the smooth cuticle. 20. A. gracile, concentric crystals in detail. 21. A. luschnatianum, amphibrachyparacytic stoma. Note long epidermal cells. 22. A. minarum, brachyparatetracytic stoma. Note conspicuous cuticular striations. 23. Anthurium sp. 2, anomocytic stoma. 24. A. intermedium, brachyparacytic stoma. $\operatorname{Bar}=25 \mu \mathrm{m}(20,22-24), 50 \mu \mathrm{m}(17,18,21), 100 \mu \mathrm{m}(19)$. 
(figuras 27-28). Em menor aumento, a face abaxial não apresentou ondulações na superfície da folha em visão transversal, sendo reta em todas as espécies estudadas (tabela 4).

Os estômatos em seção transversal podem estar no mesmo nível das demais células epidérmicas ou acima delas. Estômatos elevados ocorrem na epiderme da face abaxial em A. gracile, A. intermedium, A. minarum e A. miquelianum. Em $A$. gracile estômatos acima do nível das células epidérmicas são raros na face adaxial (figura 26).

O mesofilo é uniforme, não apresentando diferenciação entre os parênquimas paliçádico e esponjoso. As células do mesofilo apresentam disposição compacta em Anthurium sp. 1 (figura 29), A. gracile, $A$. loefgrenii, A. miquelianum e Anthurium sp. 2, exceção para A. acutum, A. intermedium, A. luschnatianum (figura 30 ) e $A$. minarum, onde podem ser encontrados espaços intercelulares mais visíveis.
O esclerênquima é representado apenas por calotas de fibras associadas aos feixes vasculares (figuras 29, 31), exceto em $A$. luschnatianum, espécie que não apresenta fibras (figura 32).

Cristais de oxalato de cálcio são representados por drusas, presentes em todas as espécies e por ráfides, ocorrentes no mesofilo de $A$. gracile e $A$. intermedium. As drusas ocorrem na epiderme de A. acutum, A. minarum, Anthurium sp. 1 e A. miquelianum (tabela 4). Estruturas de coloração amarelada, compostas por feixes de cristais em forma de agulha dispostos de maneira concêntrica estão presentes na epiderme e eventualmente no mesofilo, ocorrendo em maior quantidade em A. gracile e em A. minarum (figuras 19-20, 25, 27). Testes histoquímicos indicam cristais de natureza flavonoídica, mais especificamente de diosmina e não de hesperedina, tal como encontrado nas folhas. Não foram encontrados cristais de caroteno na espata das espécies analisadas.

Tabela 4. Anatomia da espata de espécies de Anthurium, seção transversal. (Presença (1) ou ausência (0) dos caracteres selecionados. Caracteres: $1=$ drusa (epiderme da face abaxial); $2=$ drusa (epiderme da face adaxial); $3=$ células tabulares (epiderme da face abaxial); 4 = estômatos (epiderme da face adaxial); $5=$ estômatos (epiderme da face abaxial); $6=$ estômatos elevados (epiderme da face abaxial); 7 = estômatos no mesmo nível das demais células da epiderme; $8=$ calota de fibras; 9 = espaços intercelulares no mesofilo; $10=$ mesofilo compacto; $11=$ células altas (epiderme da face adaxial); $12=$ ondulações (face abaxial); 13 = ráfides (parênquima); 14 = cutícula lisa (epiderme da face abaxial); 15 = cutícula pouco estriada (epiderme da face abaxial); 16 = cutícula muito estriada (epiderme da face abaxial); 17 = cutícula lisa (epiderme da face adaxial); 18 = cutícula pouco estriada (epiderme da face adaxial); 19 = cutícula muito estriada (epiderme da face adaxial); $20=$ cristais de natureza flavonoídica (epiderme da face adaxial); 21 = cristais de natureza flavonoídica (epiderme da face abaxial); 22 = glândula (epiderme da face adaxial)).

Table 4. Spathe anatomy of Anthurium species, transversal section. (Presence (1) or absence (0) of selected characters. Characters: $1=$ druses (abaxial surface epidermis); 2 = druses (adaxial surface epidermis); $3=$ tabular cells (abaxial surface epidermis); $4=$ stomata (adaxial surface epidermis); $5=$ stomata (abaxial surface epidermis); $6=$ raised stomata (abaxial surface epidermis); $7=$ stomata at the same level with other epidermal cells; $8=$ fibre cap; $9=$ mesophyll with large intercellular spaces; $10=$ compact mesophyll; 11 = tall epidermal cells (adaxial surface epidermis); 12 = mounds (abaxial surface); 13 = raphides (parenchyma); $14=$ smooth cuticle (abaxial surface epidermis); 15 = less striated cuticle (abaxial surface epidermis); $16=$ striated cuticle (abaxial surface epidermis); 17 = smooth cuticle (adaxial surface epidermis); $18=$ less striated cuticle (adaxial surface epidermis); 19 = striated cuticle (adaxial surface epidermis); 20 = flavonoid crystals (adaxial surface epidermis); 21 = flavonoid crystals (abaxial surface epidermis); 22 = gland (adaxial surface epidermis)).

\begin{tabular}{lcccccccccccccccccccccc}
\hline Espécies & 1 & 2 & 3 & 4 & 5 & 6 & 7 & 8 & 9 & 10 & 11 & 12 & 13 & 14 & 15 & 16 & 17 & 18 & 19 & 20 & 21 & 22 \\
\hline A. acutum & 0 & 1 & 1 & 1 & 1 & 1 & 1 & 1 & 1 & 0 & 0 & 0 & 0 & 0 & 0 & 1 & 0 & 0 & 1 & 0 & 0 & 0 \\
A. gracile & 0 & 0 & 1 & 1 & 1 & 1 & 0 & 1 & 0 & 1 & 0 & 0 & 1 & 1 & 0 & 0 & 1 & 0 & 0 & 1 & 0 & 0 \\
A. intermedium & 0 & 0 & 1 & 0 & 1 & 1 & 0 & 1 & 1 & 0 & 0 & 0 & 1 & 0 & 1 & 0 & 0 & 1 & 0 & 0 & 0 & 0 \\
A. loefgrenii & 0 & 0 & 1 & 1 & 1 & 0 & 1 & 1 & 0 & 1 & 0 & 0 & 0 & 1 & 0 & 0 & 1 & 0 & 0 & 0 & 0 & 0 \\
A. luschnatianum & 0 & 0 & 1 & 1 & 1 & 0 & 1 & 0 & 1 & 0 & 0 & 0 & 0 & 0 & 1 & 0 & 1 & 0 & 0 & 0 & 0 & 0 \\
Anthurium sp. 1 & 1 & 1 & 1 & 1 & 1 & 0 & 1 & 1 & 0 & 1 & 0 & 0 & 0 & 0 & 0 & 1 & 0 & 0 & 1 & 0 & 0 & 0 \\
A. minarum & 0 & 1 & 0 & 1 & 1 & 1 & 1 & 1 & 1 & 0 & 1 & 0 & 0 & 0 & 0 & 1 & 0 & 0 & 1 & 1 & 1 & 1 \\
A. miquelianum & 1 & 0 & 1 & 1 & 1 & 1 & 0 & 1 & 0 & 1 & 0 & 0 & 0 & 1 & 0 & 0 & 0 & 1 & 0 & 0 & 0 & 0 \\
Anthurium sp. 2 & 0 & 0 & 1 & 1 & 1 & 1 & 1 & 1 & 0 & 1 & 0 & 0 & 0 & 0 & 1 & 0 & 0 & 1 & 0 & 0 & 0 & 0 \\
\hline
\end{tabular}



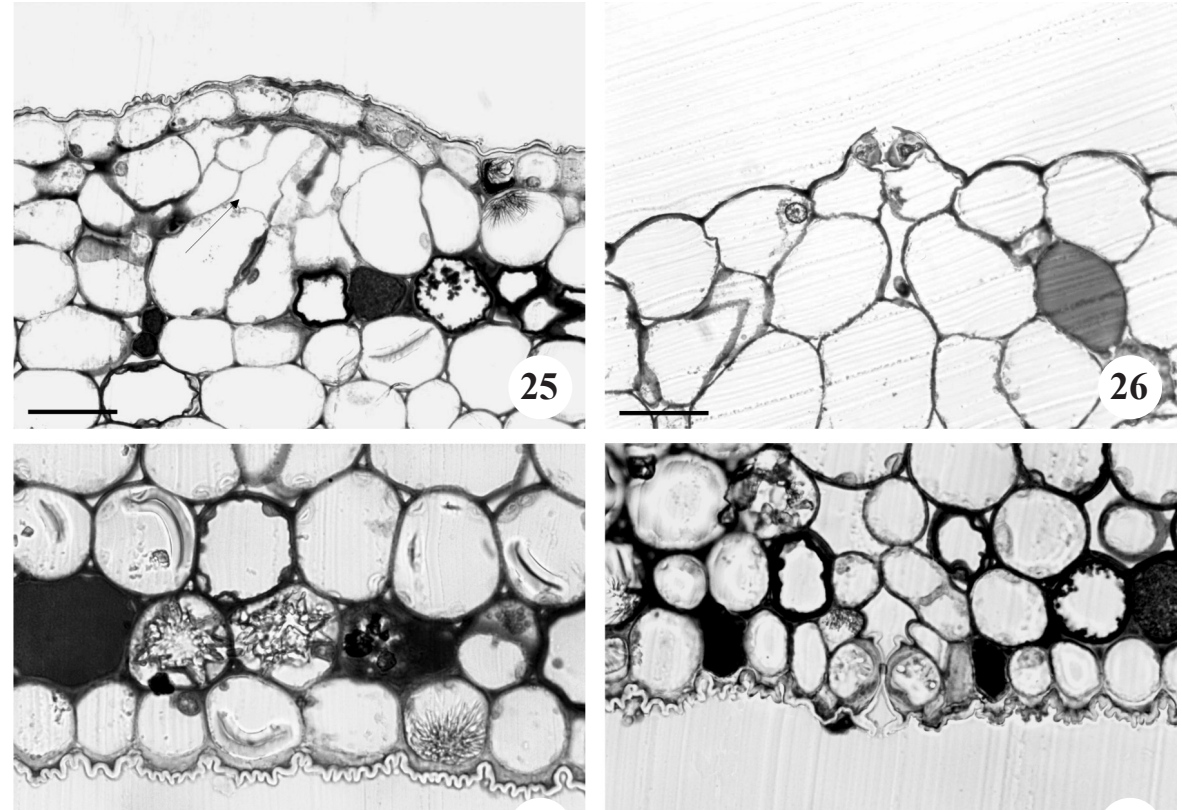

27
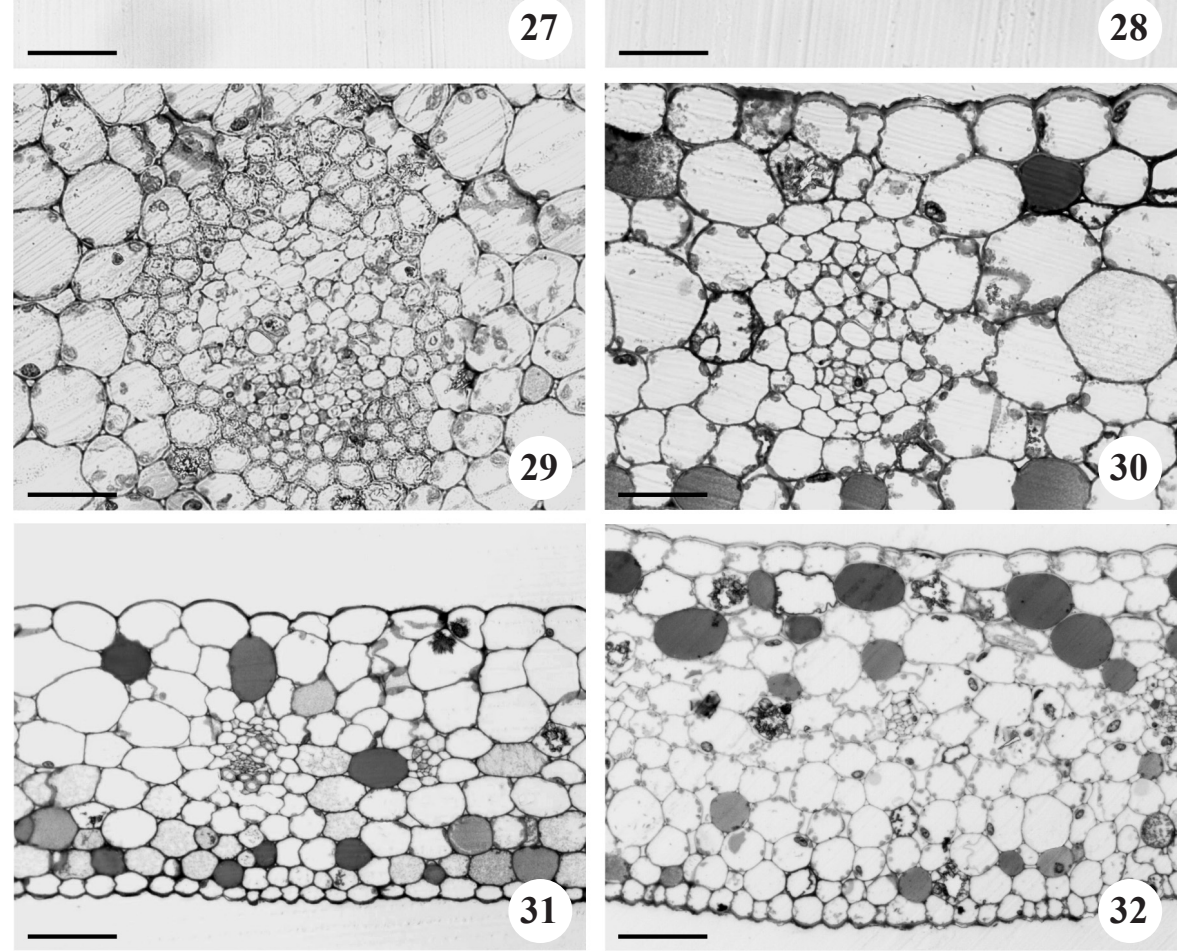

Figuras 25-32. Espata. Seções transversais. 25. Anthurium minarum, glândula epidérmica na face adaxial (seta). 26. A. gracile, estômato e cutícula lisa, epiderme da face adaxial. 27. A. minarum, drusas no parênquima, feixe concêntrico de estruturas cristalinas e cutícula estriada na epiderme da face adaxial. 28. A. minarum, estômato na epiderme da face abaxial. 29. Anthurium sp. 1. feixe vascular com calota de fibras. 30. A. luschnatianum, feixe vascular sem calota de fibras. 31. A. gracile, mesofilo com células compactadas. 32. A. luschnatianum, mesofilo com espaços intercelulares. Barra $=25 \mu \mathrm{m}(27,28), 50 \mu \mathrm{m}(25,26$, $29,30), 100 \mu \mathrm{m}(31,32)$.

Figures 25-32. Spathe. Transversal sections. 25. Anthurium minarum, epidermal gland on the adaxial surface (arrow). 26. A. gracile, stoma and smooth cuticle on the adaxial surface epidermis. 27. A. minarum, druses in the parenchyma, concentric crystals and striated cuticle on the adaxial surface epidermis. 28. A. minarum, stoma on the abaxial surface epidermis. 29. Anthurium sp. 1, vascular bundles with fibre cap. 30. A. luschnatianum, vascular bundle without fibre cap. 31. A. gracile, mesophyll with highly compacted cells. 32 . A. luschnatianum, mesophyll with intercellular spaces. Bar $=25 \mu \mathrm{m}(27,28)$, $50 \mu \mathrm{m}(25,26,29,30), 100 \mu \mathrm{m}(31,32)$. 
Glândulas estão presentes apenas na face adaxial da espata de A. minarum (figura 25).

Análises estatísticas - A análise de agrupamento gerou resultados distintos para folha e espata (figuras $33 \mathrm{~A}, \mathrm{~B}$ ). Para a folha, os coeficientes de distanciamento variaram de 0,0 a 3,3, com os valores de UPGMA indo de 1,7 a 2,8, enquanto o índice cofenético foi de $0,8(P<0,001)$. Já para espata, os coeficientes de distanciamento variaram de 0,0 a 3,7, com os valores de UPGMA indo de 2,0 a 3,0, enquanto o índice cofenético foi de $0,7(P<0,001)$.

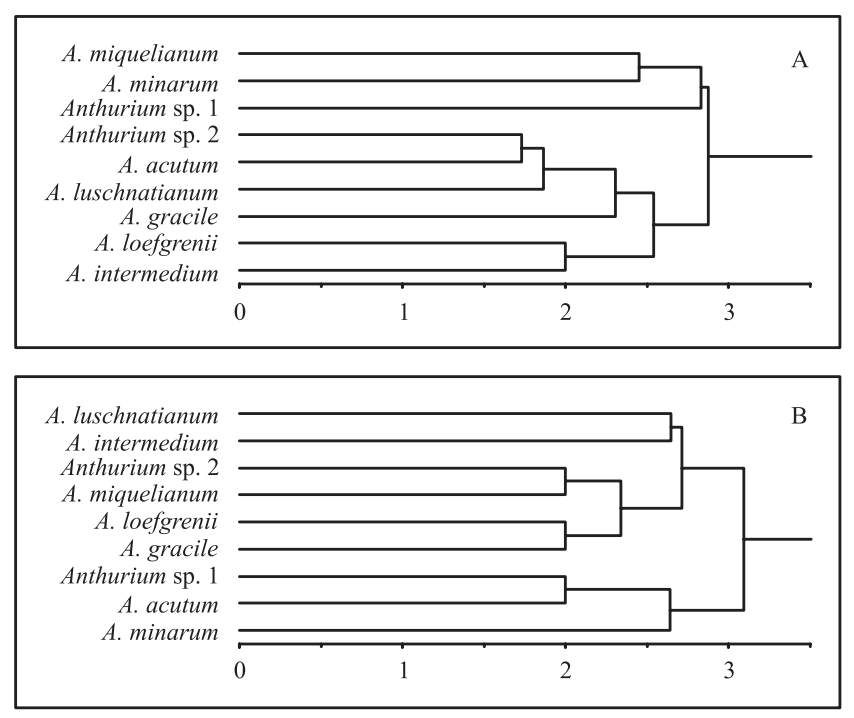

Figura 33. Análise de agrupamento obtida por distância Euclidiana e UPGMA, baseada na presença e ausência de caracteres anatômicos distintos em espécies de Anthurium. A. Folha. B. Espata.

Figure 33. Clustering analysis obtained with Euclidean distance and UPGMA algorithm, based on the presence or absence of anatomical characters in Anthurium species. A. Leaf. B. Spathe.

\section{Discussão}

Keating (2002) em sua revisão sobre anatomia da família Araceae sugere diferentes caracteres anatômicos foliares, em seção paradérmica e transversal, com potencial para diagnose taxonômica. Segundo o autor, a parede anticlinal das células epidérmicas, em visão paradérmica, pode se apresentar desde reta e ondulada a extremamente sinuosa para o gênero Anthurium. Todas as espécies aqui estudadas apresentam tanto nas folhas como na espata paredes retas a levemente onduladas.
Para as espécies analisadas neste trabalho, no entanto, a epiderme da espata em seção paradérmica apresenta diferenças quanto ao tamanho e distribuição das células em comparação com a epiderme foliar. Nas folhas as células epidérmicas são curtas, com distribuição aleatória, enquanto na espata as células são alongadas e distribuídas paralelamente ao sentido longitudinal do órgão. Essa última disposição é a geralmente encontrada em folhas de monocotiledôneas (Metcalfe 1963). No entanto Mayo (1986) mostra células pequenas aleatoriamente distribuídas na epiderme da espata de espécies de Philodendron (Araceae).

Cutícula sem ornamentações é um caráter freqüente na família Araceae, embora cutícula estriada possa ocorrer no gênero Anthurium (Potiguara \& Nascimento 1994). As espécies analisadas neste trabalho apresentam cutícula lisa na região intercostal das folhas, exceto A. minarum e Anthurium sp. 1, que apresentam cutícula levemente estriada em ambas as faces da folha e na face abaxial, respectivamente. $\mathrm{Na}$ espata, cutícula estriada ocorre com mais freqüência, estando presente em pelo menos uma das faces na maioria das espécies, com cutícula lisa em ambas as faces ocorrendo apenas em $A$. gracile, $A$. loefgrenii e $A$. luschnatianum. Estriações na cutícula foliar e a ocorrência de cutícula lisa na espata são característica não encontradas por Mantovani \& Pereira (2005) para a subseção Flavescentiviridia.

Mayo (1986) e Keating (2002) constataram que em visão transversal, alguns gêneros de Araceae apresentam o contorno das paredes periclinais das células epidérmicas, bem como a proporção altura/largura, com valores diagnósticos para a taxonomia. Nas espécies estudadas a epiderme foliar de ambas as faces apresentam células tabulares com paredes periclinais variando de retas a convexas, não revelando diferenças entre as espécies. O mesmo resultado ocorre com a epiderme das espatas analisadas. Exceção para Anthurium minarum, visto que suas células epidérmicas da face abaxial da espata são tipicamente colunares, fato que a distingue das demais espécies.

A presença de hipoderme é citada por Mantovani (1999a) para as espécies Philodendron alternans Schott e Philodendron crassinervium Lindley. Keating (2002) cita que a mesma estrutura pode ocorrer em algumas espécies de Anthurium. Este tecido é ausente na folha e espata de todas as espécies estudadas neste trabalho, exceto na folha de $A$. gracile. Por outro lado, divisões periclinais na epiderme, que podem induzir a formação de epiderme múltipla, estiveram presentes apenas nas duas faces da folha de $A$. miquelianum, entretanto por 
não apresentar-se de forma contígua não foram capazes de constituir epiderme múltipla.

O número e distribuição das células subsidiárias dos estômatos variam significantemente em Araceae (French et al 1995). Keating (2002) cita estômatos braquiparacíticos e suas variações (anfibraquiparacítico, braquiparatetracítico, braquiparahexacítico, braquiparaoctocítico) além de estômato unipolar para a família. Todos esses tipos estomáticos foram encontrados nas espécies de Anthurium estudadas no presente trabalho. Foram citados por Keating (2002) os tipos anfibraquiparacítico, braquiparacítico e braquiparahexacítico para o gênero Anthurium. Entretanto, o tipo anomocítico considerado raro para as Araceae (Grear 1973, Keating 2002) e o anisocítico foram encontrados na espata das espécies estudadas, exceto em $A$. acutum.

Segundo Lindorf(1980), células subsidiárias médias a grandes caracterizam o tipo estomático braquiparacítico em Anthurium, como é também observado aqui para folhas das espécies estudadas. Entretanto, na espata das mesmas espécies predominam células subsidiárias pequenas.

Quase todos os gêneros de Araceae apresentam estômatos distribuídos aleatoriamente nas folhas (Keating 2002), com exceção de Gymnostachys e Lemnoideae, onde o eixo polar dos estômatos é paralelo ao eixo da folha. A orientação do estômato em visão paradérmica varia entre as folhas das espécies estudadas, como também o posicionamento dos estômatos em seção transversal. A orientação dos estômatos na folha é ao acaso. $\mathrm{Na}$ espata, a orientação dos estômatos é paralela ao eixo do órgão, tal como é freqüentemente citado para gramíneas e para outras monocotiledôneas (Vieira \& Mantovani 1995). Em seção transversal, os estômatos da espata da maioria das espécies estudadas estão posicionados acima das demais células epidérmicas na face abaxial. Em A. loefgrenii, Anthurium sp. 1 e A. miquelianum os estômatos ocorrem no mesmo nível das demais células epidérmicas na face abaxial da espata.

Poucos estudos analisaram o uso potencial das características do mesofilo para determinação taxonômica em Araceae. Keating (2002, 2003) sugere a tipologia baseada na ocorrência de parênquima paliçádico e nos tipos de aerênquima, sendo típico o mesofilo dorsiventral para as folhas das aráceas (Mantovani 1999a, Keating 2000). Para as espécies de Anthurium analisadas neste trabalho, o mesofilo da espata é sempre uniforme com células esponjosas compactas, sem aerênquima. Somente A. acutum, A. intermedium e A. luschnatianum apresentam espaços intercelulares maiores na espata.
Colênquima e esclerênquima são citados para Araceae (French 1997). Keating (2002) sugere cinco tipos distintos de colênquima em aráceas, baseado na distribuição em visão transversal (calotas ao redor do floema, bandas, bandas interrompidas, faixas entre os feixes vasculares, faixas alinhadas aos feixes). Os tipos de bandas e calotas ao redor do floema são citados para Anthurium (Keating 2002). No presente grupo de espécies, foi encontrado apenas o tipo banda, na face abaxial da nervura central. Paredes com espessamento de celulose foram encontradas nas células adjacentes à epiderme da face adaxial da nervura central, mas essas não poderiam ser caracterizadas em colênquima devido ao pequeno comprimento em visão longitudinal (Esau 1977). Em alguns casos o parênquima clorofiliano presente na face adaxial da nervura central é substituído por parênquima paliçádico, como em Anthurium sp. 1, que apresenta uma faixa contínua de paliçádico abrangendo todo o mesofilo e a nervura central. Essa ocorrência é citada por Keating (2002) para outras espécies de Anthurium. Embora presente nas folhas, o colênquima é ausente nas espatas. No entanto, Mayo (1986) cita a presença de colênquima nas espatas de espécies de Philodendron.

Esclereídes e fibras são citadas para Araceae (Keating 2002). French (1997) sugere que fibras de esclerênquima em Anthurium podem estar associadas, ou não, ao floema. Keating (2002), sugere para o mesmo gênero a ocorrência de fibras associadas aos feixes vasculares podendo formar bainha ou como calotas sobre o floema e/ou xilema. As folhas estudadas neste trabalho apresentam fibras formando bainhas associadas aos feixes vasculares, o que ocorre como calotas na espata de quase todas as espécies, entretanto fibras não são encontradas na espata de $A$. luschnatianum.

Keating (2002) e French \& Tomlinson (1981) citam feixes colaterais ocorrendo nas folhas de Araceae. Nas espécies analisadas neste trabalho os feixes vasculares são caracterizados por muitos elementos de proto e metaxilema, adjacentes a um floema semicircular, correspondendo ao tipo 1 da classificação de Keating (2000).

A ocorrência de diferentes tipos de cristais de oxalato de cálcio (drusas, ráfides, areia, prismáticos e, embora raros, estilóides) é citada para Araceae (Gemia \& Hillson 1985, Mantovani 1997, Keating 2003). Keating (2002) mostra que dois tipos ou mais de cristais podem ocorrer simultaneamente no mesmo órgão em Araceae, com ráfides e drusas ocorrendo nas espécies de Anthurium. Prychid \& Rudall (1999) demonstram que a ocorrência e distribuição de cristais podem ser úteis para as propostas 
taxonômicas em monocotiledôneas. Aqui drusas ocorrem não só no mesofilo, mas também na epiderme de folha e espata, característica não citada por Keating (2000, 2002) para Anthurium. Ráfides foram observadas tanto nas folhas quanto nas espatas, característica não citada por Mantovani \& Pereira (2005) para as espatas das espécies estudadas por eles.

Estruturas de coloração amarelada, compostas por feixes de cristais em forma de agulhas dispostos de maneira concêntrica, ocorrem na epiderme e no parênquima da folha e espata de $A$. gracile e $A$. minarum. Testes histoquímicos demonstraram que a composição química desses cristais é potencialmente diosmina e não hesperedina. Cristais de diosmina são também encontrados em Rosmarinus officinalis L. (Lamiaceae), sendo esta flavona importante na farmacologia face as propriedades anti-inflamatórias, antioxidantes e anticancerígenas (Labrid 1994). Oliveira-Pires et al. (2003), estudando a anatomia da folha e raízes de espécies do gênero Prosthechea (Orchidaceae), citam a presença de estruturas cristalinas morfologicamente semelhantes as aqui encontradas, denominando-as cristais de flavonóides. Diosmina é uma substância de natureza flavonoídica e trabalhos posteriores poderão responder se ambas estruturas cristalinas são de mesma natureza química. Tanto aqui como no trabalho de Oliveira-Pires et al. (2003), tais estruturas não ocorreram em todas as espécies analisadas, apresentando potencial taxonômico. Cristais prismáticos aciculares de coloração alaranjada também são encontrados na epiderme e no mesofilo das folhas de $A$. gracile, A. minarum, A. intermedium, Anthurium sp. 1 e A. miquelianum. A alteração cromática de laranja para azul sob testes histoquímicos apropriados indica presença de cristais de caroteno (Metcalfe \& Chalk 1979, Appezzato-da-Glória \& Carmello-Guerreiro 2006). Prychid \& Rudall (1999) afirmam que cristais têm potencial de uso para a diagnose taxonômica. Mantovani \& Pereira (2005) não citam a presença dessas estruturas de diosmina ou caroteno para outras espécies da subseção Flavescentiviridia.

Estruturas secretoras representadas por glândulas punctiformes foram encontradas distribuídas aleatoriamente na face abaxial da folha e adaxial da espata apenas de A. minarum, fato citado por Lyndorf (1980), Keating (2000) e Temponi et al. (2006) para Anthurium scandens (Aubl.) Engl.

A espata é uma estrutura reprodutiva com morfologia funcional relacionada à polinização (Gottsberger \& Amaral 1984). Em alguns gêneros como Gymnostachys, Orontium e Pothoidium, a espata é ausente, sendo substituída na posição e função por uma folha apical
(Grayum 1990). Esta similaridade com as folhas estimulou comparações anatômicas e morfológicas entre folha e espata, fazendo com que alguns autores caracterizassem a espata como "leaf like structures" (sensu Grayum 1990).

Keating (2002) propõe um caminho filogenético em relação à especialização anatômica em Araceae baseada em análises morfológicas e moleculares (French et al. 1995, Keating 2000). Seguindo essa proposta, alguns caracteres anatômicos presentes aqui na espata das espécies estudadas (venação paralela, mesofilo uniforme, presença de estômato anomocítico, camada de hipoderme, aerênquima pouco desenvolvido, ausência de colênquima e presença de estruturas secretoras) poderiam ser caracteres plesiomórficos em relação aos caracteres anatômicos foliares (venação reticular, mesofilo dorsiventral, ausência de estômato anomocítico, ausência de hipoderme, presença de parênquima paliçádico, aerênquima desenvolvido e presença de colênquima). Mantovani \& Pereira (2005) também encontraram resultados semelhantes para outras nove espécies de Anthurium da mesma subseção aqui analisada. Tais resultados poderiam representar distintas taxas de evolução da anatomia de folha e espata, ou uma linha distinta de especialização da anatomia da espata. Para Philodendron, gênero considerado derivado em relação a Anthurium (Grayum 1990, French et al. 1995), Mayo (1986) e Sakuragui (1998) citam células epidérmicas diferenciadas, aerênquima desenvolvido, colênquima e ráfides na espata, ao contrário do encontrado para a espata da maioria de espécies de Anthurium analisadas.

Keating (2002) cita que o uso simultâneo de um grande número de caracteres anatômicos permite melhores resultados para diagnose taxonômica na família Araceae. A aplicação de diferentes caracteres anatômicos gerou separação das espécies aqui estudadas. Mantovani \& Pereira (2005) propõem que a espata de espécies de Anthurium seção Urospadix subseção Flavescentiviridia apresentaria maior potencial gerador de caracteres anatômicos para diagnose taxonômica do que a folha. No presente trabalho as espécies de Anthurium avaliadas mostraram-se distintas anatomicamente, fato que reforça a distinção taxonômica com bases morfológicas. Com relação ao maior potencial diagnóstico, a análise comparada dos resultados mostra uma melhor definição quando são usados caracteres de espata. A análise de agrupamento usando caracteres foliares aproximou espécies das diferentes subseções Flavescentiviridia e Obscureviridia, como pode ser exemplificado pelos grupos A. miquelianum e A. minarum, e Anthurium sp. 2 e A. acutum. Entretanto, A. loefgrenii e $A$. intermedium ambos da subseção Flavescentiviridia 
aparecem unidos. Os dados anatômicos oriundos da espata aproximaram as espécies $A$. luschnatianum e $A$. intermedium, bem como Anthurium sp. 1 e A. acutum, ambos grupos pertencentes a subseção Flavescentiviridia, bem como, isolou A. minarum, uma das poucas espécies de Anthurium com glândulas epidérmicas. Entretanto, com caracteres anatômicos da folha a aproximação entre as espécies citadas não ocorreu, pois $A$. minarum apresentase agrupada à espécie $A$. miquelianum, embora sejam morfologicamente distintas e pertençam a diferentes subseções. Tais resultados reforçam um maior potencial diagnóstico para caracteres anatômicos oriundos da espata.

Agradecimentos - O presente trabalho foi realizado com apoio do CNPq (Conselho Nacional de Desenvolvimento Científico e Tecnológico), através de concessão de bolsa de iniciação científica para segunda autora. Os autores agradecem a Dra. Suzana Leitão (NPPN/UFRJ), pela discussão sobre a natureza química dos cristais de flavonóide, e também à Faperj (Processo 171.174/2006), pelo financiamento do projeto.

\section{Referências bibliográficas}

APPEZZATO-DA-GLÓRIA，B. \& CARMELLO-GUERREIRO, S.M. 2006. Anatomia vegetal. 2ª ed. UFV, Viçosa.

COELHO, M.A.N. 2004. Taxonomia e biogeografia de Anthurium (Araceae). Seção Urospadix, subseção Flavescentiviridia. Tese de doutorado, Universidade Federal do Rio Grande do Sul, Porto Alegre.

COELHO, M.A.N. 2007. Araceae do estado de São Paulo. In Livro vermelho das espécies vegetais ameaçadas do Estado de São Paulo. (M.C.H. Mamede, V.C. Souza, J. Prado, F. Barros, M.G.L. Wanderley \& J.G. Rando, eds.). Instituto de Botânica, São Paulo, p.53-56.

COELHO, M.A.N., MAYO, S.J. \& WAECHTER, J.L. 2009. Revisão taxonômica de espécies de Anthurium (Araceae) seção Urospadix subseção Flavescentiviridia. Rodriguésia 60:799-864.

COELHO, M.A.N. \& MAYO, S.J. 2007. Typifications of names of Brazilian taxa of Anthurium sect. Urospadix (Araceae). Taxon 56:211-225.

CROAT, T.B. 1988. Ecology and life forms of Araceae. Aroideana 11:4-56.

ESAU, K. 1977. Anatomy of seed plants. $2^{\text {nd }}$ ed; John Wiley \& Sons, New York.

FRENCH, J.C. 1997. Vegetative anatomy. In The genera of Araceae (S.J. Mayo, J. Bogner \& P.C. Boyce, eds.). Royal Botanic Gardens, Kew, p.9-29.

FRENCH, J.C. \& TOMLINSON, P.B. 1981. Vascular patterns in stems of Araceae: subfamily Monsteroideae. American Journal of Botany 68:713-729.
FRENCH, J.C., CHUNG, M. \& HUR, Y. 1995. Chloroplast DNA phylogeny of the Ariflorae. In Monocotyledons: systematics and evolution (P.J. Rudall, P.J. Cribb, D.F. Cutler \& M. Gregory, eds.). Academic Press, London, p.255-275.

GEMIA, J.M. \& HILLSON, C.J. 1985. The occurrence, type and location of calcium oxalate crystals in the leaves of fourteen species of Araceae. Annals of Botany 56: 351-361.

GENTNER, G. 1905. Über die Vorläuferspitzen der Monokotylen. Flora 95:327-383.

GOTTSBERGER, G. \& AMARAL, A. 1984. Pollination strategies in Brazilian Philodendron species. Berichte der Deutschen Botanischen Gesellschaft 97:391-410.

GOVAERTS, R., FRODIN, D.G., BORGNER, J., BOYCE, P., COSGREFF, B., CROAT, T.B., GONÇALVES, E.G., GAYUM, M., HAY, A., HETTERSCHEID, W., LANDOLT, E., MAYO, S.J., MURATA, J., NGUYEN, V.D., SAKURAGUI, C.M., SINGH, Y., THOMPSON, S. \& ZHU, G. 2002. World checklist and bibliography of Araceae (and Acoraceae). Royal Botanic Garden, Kew.

GRAYUM, M.H. 1990. Evolution and phylogeny of the Araceae. Annals of the Missouri Botanical Garden 77:628-697.

GREAR, J.W. 1973. Observations on the stomatal apparatus of Orontium aquaticum (Araceae). Botanical Gazette 134:151-153.

JOHANSEN, D.A. 1940. Plant microtechnique. Mc-Graw Hill Book Co. Inc., New York.

KEATING, R.C. 2000. Collenchyma in Araceae: trends and relation to classification. Botanical Journal of the Linnean Society 134:203-214.

KEATING, R.C. 2002. Anatomy o the monocotyledons IX. Acoraceae and Araceae. Clarendon Press, Oxford.

KEATING, R.C. 2003. Leaf anatomical characters and their value in understand morphoclines in the Araceae. Botanical Review 68:510-523.

KÖPPEN, W. 1948. Climatologia: con un estudio de los climas de la tierra. Fondo de Cultura Econômica, México.

LABRID, C. 1994. Pharmacologic properties of Daflon $500 \mathrm{mg}$. Angiology 45:524-530.

LINDORF,H. 1980. Leafstructure of 15 shademonocotyledons of the cloud forest of Rancho Grande: 1. Bifacials: Araceae, Marantaceae, Musaceae. Memorias de la Sociedad de Ciencias Naturales "La Salle" 40:19-72.

LORENZO, L., MANTUANO, D.G. \& MANTOVANI, A. 2009. Comparative leaf ecophysiology and anatomy of seedlings, young and adult individuals of the epiphytic aroid Anthurium scandens (Aubl.) Engl. Environmental and Experimental Botany 68:314-322.

MANTOVANI, A. 1997. Considerações iniciais sobre a conquista do hábito epifítico na família Araceae. Dissertação de mestrado, Universidade Federal do Rio de Janeiro, Rio de Janeiro. 
MANTOVANI, A. 1999a. Leaf morphophysiology and distribution of epiphytic aroids along a vertical gradient in a Brazilian rain forest. Selbyana 20:241-249.

MANTOVANI, A. 1999b. A method to improve leaf succulence quantification. Brazilian Archives of Biology and Technology 42:9-14.

MANTOVANI, A. 2000. Leaf orientation in epiphytic aroids: effect on water and temperature balance of the leaves. Leandra 19:91-103.

MANTOVANI, A. \& PEREIRA, T.E. 2005. Comparative anatomy of leaf and spathe of nine species of Anthurium (section Urospadix; sub-section Favescentiviridia) (Araceae) and their diagnostic potential for taxonomy. Rodriguesia 56:146-160.

MANTOVANI, A. \& VIEIRA, R.C. 2000. Leaf micromorphology of Antartic pearlwort Colobanthus quitensis (Kunth) Bartl. Polar Biology 23:531-538.

MANTOVANI, A., PEREIRA, T.E. \& COELHO, M.A.N. 2009. Leaf midrib outline as a diagnostic character for taxonomy in Anthurium subsection Flavescentiviridia (Araceae). Hoehnea 36:269-277.

MAYO, S.J. 1986. Systematics of Philodendron Schott (Araceae) with special reference to inflorescence characters. PhD Thesis, University of Reading, Reading.

METCALFE, C.R. 1963. Comparative anatomy as a modern botanical discipline, with special reference to recent advances in the systematic anatomy of monocotyledons. Advances in Botanical Research 1:101-147.

METCALFE, C.R. \& CHALK, L. 1979. Anatomy of the dicotyledons. 2 ${ }^{\text {nd }}$ ed; Oxford University Press, New York.

O'BRIEN, T.P. \& MCCULLY, M.E. 1981. The study of plants structure: principles and selected methods. Termarcarphi Pty, Melbourne, p.446-455.
OLIVEIRA-PIRES, M.F., MELO-DE-PINNA, G.F. \& FELIX, L.P. 2003. Taxonomic separation of the genera Prosthechea and Encyclia (Laeliinae: Orchidaceae) using leaf and root anatomical features. Botanical Journal of the Linnean Society 143:293-303.

POTIGUARA, R.C.V. \& NASCIMENTO, M.E. 1994. Contribuição à anatomia dos órgãos vegetativos de Heteropsis jenmani Oliv. (Araceae). Boletim do Museu Paraense Emílio Goeldi 10:237-247.

PRYCHID, C.J. \& RUDALL, P.J. 1999. Calcium oxalate crystals in monocotyledons: a review of their structure and systematics. Annals of Botany 84:725-739.

RADA, F. \& JAIMEZ, R. 1992. Comparative ecophysiology and anatomy of terrestrial and epiphytic Anthurium bredemeyeri Schott in a tropical Andean cloud forest. Journal of Experimental Botany 43:723-727.

RUZIN, S.E. 1992. Plant microtechnique and microscopy. Oxford University Press, New York.

SAKURAGUI, C.M. 1998. Taxonomia e filogenia das espécies de Philodendron, seção Calostigma (Schott) Pfeiffer no Brasil. Tese de doutorado, Universidade de São Paulo, São Paulo.

SCHNEIDER, S.M. \& COELHO, M.A.N. 2006. Inventário das Araceas do palácio de São Cristóvão e do horto botânico do Museu Nacional, Quinta da Boa VistaRio de Janeiro, Brasil. Publicações Avulsas do Museu Nacional 113:2-28.

TEMPONI, L.G., GARCIA, F.C.P., SAKURAGUI, C.M. \& CARVALHO-OKANO, R.M. 2006. Araceae do Parque Estadual do Rio Doce, MG, Brasil. Acta Botanica Brasilica 20:87-103.

VALENTIN, J.L. 2000. Ecologia numérica: uma introdução à análise multivariada de dados ecológicos. Editora Interciência, Rio de Janeiro.

VIEIRA, R.C. \& MANTOVANI, A. 1995. Anatomia foliar de Deschampsia antarctica Desv. Revista Brasileira de Botânica 18:207-220. 